\title{
Pozycja prawna młodego rolnika w Polsce w świetle rezolucji Parlamentu Europejskiego z 29 maja 2018 r.
}

\section{Wprowadzenie}

Rezolucja Parlamentu Europejskiego z 29 maja 2018 r. w sprawie wdrażania narzędzi Wspólnej Polityki Rolnej (WPR) dla młodych rolników w Unii Europejskiej po reformie z 2013 r. (2017/2088(INI))¹ ma zwrócić uwagę unijnych organów i europejskich instytucji, a także rządów poszczególnych państw członkowskich na pilną potrzebę należytego ukształtowania i zabezpieczenia pozycji młodych rolników w unijnym prawodawstwie oraz w regulacjach krajowych jako warunku prawidłowego przebiegu procesu przemian strukturalnych, w tym pokoleniowych i własnościowych, na obszarach wiejskich w XXI wieku.

Diagnozy i zalecenia zawarte w tej rezolucji, które przekazano Radzie i Komisji, Europejskiemu Trybunałowi Obrachunkowemu oraz rządom i parlamentom państw członkowskich, zostały przygotowane na podstawie analizy obowiązującego prawa ${ }^{2}$, jak również wyników badań naukowych

* Szkoła Główna Gospodarstwa Wiejskiego w Warszawie.

${ }^{1}$ Dz. Urz. UE C 2020.76.11 [dalej: rezolucja PE].

${ }^{2}$ Chodzi w szczególności o przepisy zawarte w rozporządzeniu Parlamentu Europejskiego i Rady (UE) nr 1305/2013 z 17 grudnia 2013 r. w sprawie wsparcia rozwoju obszarów wiejskich przez Europejski Fundusz Rolny na rzecz Rozwoju Obszarów Wiejskich (EFRROW) i uchylającym rozporządzenie Rady (WE) nr 1698/2005 (Dz. Urz. UE L 2013.347.487, dalej: rozporządzenie 1305/2013), w rozporządzeniu Parlamentu Europejskiego i Rady (UE) nr 1307/2013 z 17 grudnia 2013 r. ustanawiającym przepisy dotyczące płatności bezpośrednich dla rolników na podstawie systemów wsparcia w ramach wspólnej polityki rolnej oraz uchylającym rozporządzenie Rady (WE) nr 637/2008 i rozporządzenie Rady (WE) nr 73/2009 (Dz. Urz. UE L 2013.347.608, da- 
oraz poglądów wyrażonych w stanowiskach różnych zainteresowanych gremiów. Najważniejsze z nich zaprezentowano podczas posiedzenia Komisji Rolnictwa i Rozwoju Wsi 23 listopada 2017 r., gdzie w ramach wysłuchania publicznego przedstawiono m.in. wyniki badania pt. „Young farmers: Policy implementation after the 2013 CAP reform"3. Uwzględnione zostało również badanie Europejskiej Rady Młodych Rolników (CEJA) pt. „Young farmers are key in the future CAP"4, sprawozdanie specjalne Europejskiego Trybunału Obrachunkowego nr 10/2017 pt. „Unijne wsparcie dla młodych rolników powinno być lepiej ukierunkowane, tak aby zapewniało rzeczywisty wkład w wymianę pokoleń" '5 oraz konkluzje rezolucji Parlamentu Europejskiego z 27 kwietnia 2017 r. w sprawie aktualnego stanu koncentracji gruntów rolnych w UE: jak ułatwić rolnikom dostęp do gruntów? (2016/2141(INI)) ${ }^{6}$.

Celem rozważań jest skonfrontowanie zidentyfikowanych przez Parlament Europejski potrzeb i wyzwań związanych ze współczesną rolą młodych rolników z obowiązującymi polskimi regulacjami, które kształtują ich pozycję prawną.

Zalecenia zawarte w rezolucji PE zostały poprzedzone rzetelną oceną aktualnej pozycji ekonomiczno-społecznej unijnych młodych rolników. Warto przy tym wskazać na niewielki odsetek $(6 \%)$ rolników w wieku poniżej 35 lat wśród osób prowadzących gospodarstwa rolne w Unii Europejskiej, podczas gdy ponad połowa $\mathrm{z}$ nich jest $\mathrm{w}$ wieku powyżej 55 lat. Istotne, że w ostatniej dekadzie w związku ze starzeniem się populacji wystąpiły problemy w zakresie odnowy pokoleniowej w rolnictwie, co jest szczególnie dotkliwe w sektorach hodowli zwierząt. Może to wynikać z faktu, że wspierany

lej: rozporządzenie 1307/2013) oraz w rozporządzeniu Parlamentu Europejskiego i Rady (UE) 2017/2393 z 13 grudnia 2017 r. zmieniającym rozporządzenia (UE) nr 1305/2013 w sprawie wsparcia rozwoju obszarów wiejskich przez Europejski Fundusz Rolny na rzecz Rozwoju Obszarów Wiejskich (EFRROW), (UE) nr 1306/2013 w sprawie finansowania wspólnej polityki rolnej, zarządzania nią i monitorowania, (UE) nr 1307/2013 ustanawiające przepisy dotyczące płatności bezpośrednich dla rolników na podstawie systemów wsparcia w ramach wspólnej polityki rolnej, (UE) nr 1308/2013 ustanawiające wspólną organizację rynków produktów rolnych oraz (UE) nr 652/2014 ustanawiające przepisy w zakresie zarządzania wydatkami odnoszącymi się do łańcucha żywnościowego, zdrowia zwierząt i dobrostanu zwierząt oraz dotyczącymi zdrowia roślin i materiału przeznaczonego do reprodukcji roślin (Dz. Urz. UE L 2017.350.15, dalej: rozporządzenie 2017/2393).

${ }^{3}$ Badanie pt. „Młodzi rolnicy: wdrożenie polityki po reformie WPR z 2013 r.” zlecone przez Departament Tematyczny B Parlamentu Europejskiego - Polityka Strukturalna i Polityka Spójności, https://www.europarl.europa.eu/thinktank/en/document.html?reference=IPOL_ STU(2017)602006 [dostęp: 31.01.2020].

${ }^{4}$ Badanie pt. „Młodzi rolnicy mają zasadnicze znaczenie dla przyszłości WPR” opublikowane w dniu 17 maja 2017 r., https://www.ceja.eu/press-releases/234 [dostęp: 31.03.2020].

${ }^{5} \mathrm{https}: / /$ www.eca.europa.eu/pl/Pages/DocItem.aspx?did=41529 [dostęp: 31.03 .2020 ].

${ }^{6}$ Dz. Urz. UE C 2018.298.112. 
przez ponad 50 lat w ramach WPR rozwój rolnictwa sprzyjał powiększaniu i koncentracji gospodarstw rolnych, jak również znaczącej kapitalizacji dóbr inwestycyjnych, co obecnie utrudnia przekazywanie lub udostępnianie niektórych gospodarstw młodym ludziom ze względu na wysokie nakłady kapitałowe niezbędne do przejęcia takich jednostek produkcyjnych. Ponadto w latach 2007-2013 liczba młodych rolników w całej Unii Europejskiej zmniejszyła się z 3,3 mln do 2,3 mln, a powierzchnia gospodarstw rolnych przez nich prowadzonych zmalała w tym czasie z $57 \mathrm{mln}$ do $53 \mathrm{mln}$ ha.

W świetle zmian demograficznych, takich jak wyludnianie czy starzenie się ludności na obszarach wiejskich, istotne jest stwarzanie perspektyw dla rolnictwa jako sektora nowoczesnego i atrakcyjnego, tak by zachęcić młodych ludzi do podejmowania pracy w rolnictwie. Jest to istotne zadanie w obliczu obecnej konkurencji w zakresie dostępu do gruntów między młodymi ludźmi pragnącymi rozpocząć działalność rolniczą a rolnikami $\mathrm{z}$ wieloletnim doświadczeniem, a czasami nawet między młodymi ludźmi a przedsiębiorstwami inwestycyjnymi wykazującymi zainteresowanie rolnictwem. W ocenie Parlamentu Europejskiego niedobór młodych ludzi wybierających karierę zawodową w rolnictwie stwarza zagrożenie dla stabilności gospodarczej i zrównoważonego rozwoju społecznego obszarów wiejskich, a także samowystarczalności żywnościowej i bezpieczeństwa żywnościowego UE. Zjawiska te zinterpretowano również jako zagrażające modelowi rozwoju rolnictwa opartego na gospodarstwach rodzinnych ${ }^{7}$.

W preambule rezolucji wskazano też, że nie wszystkie państwa członkowskie realizują odpowiednią politykę na rzecz podejmowania działalności rolniczej przez młodych rolników i nie wszystkie wykorzystują narzędzia, które udostępniono w ramach WPR, aby ich wspierać. Jest to sprzeczne z kierunkami ostatniej reformy WPR, w ramach której wprowadzono m.in. obowiązkowe płatności na rzecz młodych rolników w ramach pierwszego filaru (6,9 mld EUR dla 180 tys. młodych rolników), a w ramach drugiego filaru - środki takie jak wsparcie na rzecz rozpoczęcia działalności, dostęp do finansowania bądź kredytu czy możliwość wprowadzenia podprogramu tematycznego dla młodych rolników (2,6 mld EUR). W związku z tym uznano, że wymiana pokoleniowa musi być jednym z priorytetów przyszłej WPR, która powinna zapewnić wspólne ramy dla strategii krajowych dostosowanych do konkretnych potrzeb, oraz że wspieranie tej wymiany jest jednym $\mathrm{z}$ warunków wstępnych utrzymania rolnictwa w całej UE oraz zachowania żywotności i atrakcyjności obszarów wiejskich, zwłaszcza dzięki zwiększaniu różnorodności gospodarstw i wspieraniu zrównoważonego rolnictwa rodzinnego.

7 Zob. preambułę rezolucji PE, lit. A-J. 
Konieczność zmiany polityki w tym zakresie uzasadnia także to, że choć obecne środki wsparcia ułatwiają młodym rolnikom dostęp do finansowania lub kapitału, to nie rozwiązują kwestii dostępu do gruntów w celu założenia nowych gospodarstw. Dostęp ten jest przy tym jedną z głównych przeszkód stojących od lat przed młodymi rolnikami i nowymi podmiotami na rynku rolnym, która wymaga skutecznych rozwiązań. Zdaniem europejskich parlamentarzystów dostęp do gruntów utrudniają z jednej strony utrata użytków rolnych wskutek zasklepiania gleby, urbanizacji, turystyki, projektów infrastrukturalnych, zmiany sposobu użytkowania i postępującego pustynnienia w wyniku zmiany klimatu, a z drugiej - koncentracja gruntów w rękach jednego podmiotu. Także spekulacyjne podwyżki cen gruntów uznane zostały za poważny i coraz bardziej niepokojący problem nowych podmiotów i młodych rolników w wielu państwach członkowskich ${ }^{8}$.

Ważne jest też, że w świetle celów WPR młodzi rolnicy stanowią ważne źródła innowacji i przedsiębiorczości w rolnictwie, przynosząc takie korzyści, jak: wprowadzanie nowej wiedzy lub technik, rozwijanie nowych modeli biznesowych opartych na użytkownikach końcowych, opracowywanie bardziej zrównoważonych systemów gospodarki rolnej, rozwijanie nowych modeli organizacyjnych (np. upraw wspólnych, płatności zaliczkowych, finansowania społecznościowego), zacieśnianie powiązań między rolnictwem a lokalną społecznością oraz dostosowywanie tradycyjnej wiedzy do opracowywanych innowacji biznesowych (np. rzemieślniczej produkcji żywności). Istotna jest również rola młodych rolników w ramach zrównoważonego, zróżnicowanego i sprzyjającego włączeniu społecznemu sektora rolnego. Wspieranie ich może zapewnić przyszłość produkcji żywności oraz ochronę środowiska i krajobrazu wiejskiego. Młodzi rolnicy konkurują obecnie w ramach szybko rozwijającego się sektora rolnego, a innowacje, badania naukowe i rolnictwo precyzyjne mogą przyczynić się do poprawy wydajności rolnej, a jednocześnie lepszego zarządzania zasobami9.

\section{Zalecenia rezolucji Parlamentu Europejskiego}

Zalecenia zawarte $\mathrm{w}$ rezolucji PE ujęte zostały w ośmiu grupach tematycznych, istotnych ze względu na instrumenty oddziaływania na sytuację prawną i ekonomiczną młodych rolników.

Pierwsza grupa tematyczna nosi tytuł „Budżet i dostęp do finansowania”. Parlament Europejski udzielił poparcia dla utrzymania silnej Wspólnej Po-

\footnotetext{
${ }^{8}$ Ibidem, lit. $\mathrm{K}-\mathrm{O}$.

${ }^{9}$ Ibidem, lit. P-AG.
} 
lityki Rolnej z myślą o jej przyszłej reformie, mając nadzieję na zachęcenie w ten sposób młodych ludzi do rozpoczęcia działalności rolniczej. Postulował przy tym pilne wdrożenie decyzji ujętych w rozporządzeniu 2017/2393 oraz dalsze wsparcie programu dla młodych rolników przez podwyższenie maksymalnego pułapu krajowego przydziału środków do poziomu ponad $2 \%$ na płatności obowiązkowe w ramach pierwszego filaru oraz zwiększenie stawki wsparcia w ramach drugiego filaru jako zachęty do wymiany pokoleniowej. Zalecił także, aby w przyszłości uwzględnić w WPR zwiększenie środków pomocowych na rozpoczęcie działalności dla młodych rolników (zwanych dotacjami dla młodych rolników) oraz wydłużenie okresu, w którym prowadzone przez nich gospodarstwa mogą korzystać z dodatkowego wsparcia z pierwszego filaru. Parlament Europejski zalecił również wprowadzenie różnicowania wielkości pomocy m.in. w zależności od wieku i poziomu wyszkolenia młodych rolników.

W rezolucji zalecono też zwiększenie dostępu do finansowania przez dopłaty do odsetek od pożyczek dla nowych podmiotów, w tym pożyczek od prywatnych operatorów finansowych, w szczególności przez wdrożenie instrumentów finansowych umożliwiających udzielanie młodym rolnikom pożyczek na inwestycje o zerowym oprocentowaniu. Europarlamentarzyści wyrazili przy tym pogląd, że UE powinna sprzyjać powstawaniu nowych form finansowania społecznościowego w rolnictwie, które już teraz pojawiają się w przypadku nabywania gruntów z odroczonym terminem wykupu, które to finansowanie można połączyć z nowymi instrumentami finansowymi. Ponadto zalecili poprawę oceny zdolności kredytowej gospodarstw rolnych przez banki i instytucje kredytowe, w tym przez wycenę instrumentów finansowych przewidzianych w ramach WPR, jak również zwiększenie dostępu młodych rolników do możliwości oferowanych przez europejskie fundusze strukturalne i inwestycyjne, w uzupełnieniu do wsparcia przewidzianego w WPR, w zakresie opracowywania i wdrażania instrumentów finansowych w formie pożyczek, gwarancji lub funduszy kapitałowych w celu zapewnienia dostępu do finansowania osobom, które tego potrzebują. Zarekomendowano w związku z tym, by oprócz środków wsparcia zagwarantować młodym rolnikom specjalistyczne niezależne usługi doradztwa finansowego. Parlament Europejski wezwał też Komisję do zaproponowania środków wsparcia inwestycji w inteligentne rolnictwo, aby zwiększyć dostęp młodych rolników do osiągnięć technologicznych ${ }^{10}$.

Natomiast w ramach grupy zaleceń pt. „Zarządzanie wdrażanymi środkami i ich uproszczenie" Parlament Europejski zauważył, że mimo przyjęcia w wyniku reformy WPR na lata 2014-2020 nowych środków wspierających

\footnotetext{
${ }^{10}$ Zob. zalecenia rezolucji PE, pkt 1-12.
} 
młodych rolników w zakładaniu gospodarstw obciążenia administracyjne wciąż utrudniają korzystanie przez beneficjentów z tych środków. Wskazano, że ogólne zarządzanie płatnościami bezpośrednimi i środkami programu rozwoju obszarów wiejskich jest postrzegane jako bardzo złożone i trudne, w szczególności przez nowe podmioty niezaznajomione z systemem płatności. Adresaci rezolucji PE otrzymali zalecenie podjęcia większego wysiłku w celu uproszczenia procedur i skrócenia czasu potrzebnego na zatwierdzenie płatności.

Ponadto w rezolucji zwrócono uwagę na nieuczciwe praktyki handlowe w łańcuchu dostaw żywności, których narzucanie wykorzystuje znaczne siły negocjacyjne nabywców, przetwórców lub przedsiębiorców w porównaniu z ich dostawcami, co stanowi poważne zagrożenie dla stabilności działalności rolników. Wezwano więc Komisję, by przyjęła odpowiednie regulacje na szczeblu UE. Wyrażono również pogląd, że rolnicy powinni sami decydować o gospodarowaniu własnymi gruntami, gdyż aby gospodarstwa rolne mogły dobrze funkcjonować, muszą mieć swobodę i być elastyczne, jak każdy inny rodzaj przedsiębiorstwa. Według Parlamentu, aby gospodarstwa rolne były wydajne pod względem ekonomicznym, należy zapewnić im możliwość powiększania się, a tym samym osiągnięcia progowej wielkości odpowiadającej realiom gospodarczym rynku ${ }^{11}$.

W kolejnej grupie tematycznej zaleceń pt. „Dostęp do ziemi i zwalczanie masowego wykupu i dzierżawy ziemi" wyeksponowana została kwestia dostępu do gruntów, który stanowi jedną z największych przeszkód podejmowania działalności w rolnictwie. Wyraża się on w niskiej podaży gruntów oferowanych do sprzedaży lub dzierżawy w wielu regionach, a także w konkurencji ze strony innych rolników, inwestorów i użytkujących grunty na cele mieszkalne, jak również w trudnościach z uzyskaniem finansowania. Problem dostępu do gruntów zaostrza obecna struktura płatności bezpośrednich, która może prowadzić do wyższych kosztów dzierżawy i nabycia gruntów. Parlament Europejski zalecił więc zwiększenie wymaganych poziomów aktywności przy przyznawaniu płatności, z uwzględnieniem nowych modeli rolnictwa, tak aby wynagradzały one osiągnięcie określonych wyników (np. rzeczywisty czas przeznaczony na rolnictwo, przynoszenie określonych korzyści środowiskowych lub społecznych). Co ciekawe, zalecił również wprowadzenie zakazu nieuzasadnionego kumulowania dotacji z pobieraniem świadczeń emerytalnych ${ }^{12}$.

Parlament Europejski uznał ponadto, że właściciele muszą dysponować prawem do sprzedawania gruntów rolnych wybranym przez siebie nabywcom.

${ }^{11}$ Ibidem, pkt 13-27.

12 Ibidem, pkt 28. 
Zwrócił się zatem do Komisji o podjęcie działań ułatwiających przekazywanie ziem, w szczególności ich dziedziczenie, aby pomóc młodym osobom w zakładaniu gospodarstw rolnych. Jednocześnie wezwał Komisję i państwa członkowskie do podjęcia działań ograniczających spekulowanie gruntami rolnymi. Zaapelował do Komisji o ustanowienie zaleceń na szczeblu Unii Europejskiej wspierających aktywną politykę krajową w zakresie dostępu do gruntów zgodnie z najlepszymi praktykami, zaś do państw członkowskich o zapewnienie w pierwszej kolejności dostępu do gruntów rolnych nowym podmiotom i młodym rolnikom dzięki pełnemu wykorzystaniu instrumentów regulacyjnych, które zostały już w niektórych krajach wdrożone ${ }^{13}$.

W związku z tym w rezolucji PE zaproponowano, aby państwa członkowskie opracowały narzędzia, takie jak banki gruntów, w celu ułatwienia dostępu do gruntów, i mapy gruntów niezabudowanych do dyspozycji młodych rolników. Zdaniem Parlamentu młodym rolnikom powinno przysługiwać odstępstwo od obecnego limitu wynoszącego $10 \%$ na inwestycje gruntowe przewidzianego w rozporządzeniu delegowanym Komisji (UE) nr 480/2014 z 3 marca 2014 r. dotyczącym funduszy strukturalnych i przepisów ogólnych w sprawie pomocy państwa ${ }^{14}$. Pomoc należałoby bardziej ukierunkować na obszary odizolowane, słabo zaludnione lub najdotkliwiej odczuwające skutki niewystarczającej wymiany pokoleniowej ${ }^{15}$.

Parlament Europejski zalecił również, aby państwa członkowskie w ramach strategii krajowych - wspomagały świadczenie usług doradztwa rolniczego i zarządzania gospodarstwami rolnymi w celu wspierania i ułatwiania obrotu ziemią oraz wprowadzenia usług planowania dziedziczenia. Zaapelował, aby wszystkie państwa członkowskie wprowadziły wsparcie na rzecz przekazywania gospodarstw rolnych, tak aby subsydiować głównych gospodarzy w wieku powyżej 55 lat nieposiadających spadkobierców, którzy mogą na emeryturze znaleźć się w niepewnej sytuacji, pod warunkiem że przekażą część lub całość swojego gospodarstwa jednemu lub większej liczbie młodych rolników.

${ }^{13}$ Komunikat wyjaśniający Komisji w sprawie nabywania gruntów rolnych i prawa Unii Europejskiej (Dz. Urz. UE C 2017.350.5).

${ }^{14}$ Rozporządzenie delegowane Komisji (UE) nr 480/2014 z 3 marca 2014 r. uzupełniające rozporządzenie Parlamentu Europejskiego i Rady (UE) nr 1303/2013 ustanawiające wspólne przepisy dotyczące Europejskiego Funduszu Rozwoju Regionalnego, Europejskiego Funduszu Społecznego, Funduszu Spójności, Europejskiego Funduszu Rolnego na rzecz Rozwoju Obszarów Wiejskich oraz Europejskiego Funduszu Morskiego i Rybackiego oraz ustanawiające przepisy ogólne dotyczące Europejskiego Funduszu Rozwoju Regionalnego, Europejskiego Funduszu Społecznego, Funduszu Spójności i Europejskiego Funduszu Morskiego i Rybackiego (Dz. Urz. UE L 2014.138.5 ze zm.).

${ }_{15}$ Zob. zalecenia rezolucji PE, pkt 30-35. 
Zauważono też, że w wielu państwach członkowskich przeszkodą dla wymiany pokoleniowej i dostępu młodych ludzi do gruntów rolnych jest późne dziedziczenie, co może wynikać faktu, że w obecnej WPR nie przewiduje się już zachęt dla starszych rolników do przekazywania prowadzonej działalności młodszym pokoleniom. W związku z tym zalecono ponowne rozważenie wdrożenia środków mogących motywować starszych rolników do przekazywania swoich gospodarstw młodym rolnikom, takich jak ,system wycofywania się z gospodarstw rolnych" i inne zachęty do przechodzenia na emeryturę, z rekomendacją, by jednocześnie przeciwdziałać koncentracji gruntów dokonywanej przez rolników z sąsiedztwa. W rezolucji PE podkreśla się również znaczenie struktur prawnych, takich jak grupy rolne wspólnego gospodarowania (GAEC), które mogą umożliwić młodym osobom wspólne zakładanie gospodarstw i ułatwić przekazywanie gospodarstw między pokoleniami ${ }^{16}$.

Posłowie do PE wezwali również Komisję i państwa członkowskie, by wspierały korzystanie z możliwości dostępnych w ramach programu rozwoju obszarów wiejskich, aby stymulować nowe działania mające na celu wspomaganie obrotu gruntami, takie jak banki ziemi, inicjatywy na rzecz łączenia zbywców gruntów rolnych z potencjalnymi nabywcami oraz inne promowane na szczeblu lokalnym inicjatywy ułatwiające nowym podmiotom dostęp do ziemi. Ich zdaniem młodzi rolnicy na całym terytorium Unii powinni mieć dostęp do kredytów na tych samych warunkach i o takich samych stopach procentowych, których nie należy różnicować. W związku z tym PE wezwał Komisję, aby wraz z Europejskim Bankiem Inwestycyjnym opracowała odpowiednie środki wsparcia i linie kredytowe dla młodych rolników ${ }^{17}$.

Parlament Europejski podkreślił również znaczenie współpracy rolników. Zwrócił się o promowanie nowych modeli współpracy także między pokoleniami rolników przez partnerstwo, uprawy wspólne, spółdzielnie maszyn rolniczych, wieloletnią dzierżawę i inne porozumienia długoterminowe, umowy między prowadzącymi gospodarstwa rolne oraz środki na rzecz organizacji krajowych lub regionalnych zaangażowanych we wspieranie i ułatwianie usług nawiązywania kontaktów zawodowych między starszymi i młodszymi rolnikami (np. usług w zakresie obrotu gruntami). Stwierdził też, że stworzenie większej i silniejszej organizacji rolników - przez zakładanie spółdzielni i zrzeszanie się w organizacjach producentów - może przyczynić się do zwiększenia rentowności działalności rolniczej i stanowić zabezpieczenie dochodu rolników, w szczególności młodych, zapewniając

\footnotetext{
${ }^{16}$ Ibidem, pkt 38-42.

${ }^{17}$ Ibidem, pkt 43-44.
} 
pomoc w podejmowaniu decyzji produkcyjnych i jak najlepsze wykorzystanie właściwości obszarów wiejskich. W ocenie PE reforma strukturalna organizacji producentów, mająca na celu zwiększenie ich odpowiedzialności oraz zrzeszenie się większej liczby rolników, może się przede wszystkim przyczynić do ochrony i zwiększenia rentowności sektora ${ }^{18}$.

Parlament Europejski podkreślił też znaczenie spójności między lokalnymi, krajowymi i unijnymi środkami dla młodych rolników, wzywając państwa członkowskie do ułatwienia wymiany pokoleń, np. za pośrednictwem przepisów prawa spadkowego i podatkowego, zasad dostępu do ziemi, planowania przestrzennego i strategii dziedziczenia gospodarstw rolnych. Zaakcentował przy tym konieczność ułatwienia kobietom sprawiedliwego dostępu do gruntów, aby zachęcić je do osiedlania się na obszarach wiejskich i odgrywania aktywnej roli w sektorze rolnym ${ }^{19}$.

W czwartej grupie zaleceń pt. „Szkolenia, innowacje i komunikacja” zwrócono uwagę na potrzebę modernizacji szkoleń zawodowych dostępnych na obszarach wiejskich oraz nadania im większego znaczenia, przy aktywnym zaangażowaniu krajowych służb doradczych. Parlament Europejski uznał, że należy ułatwić młodym rolnikom dostęp do Europejskiego Funduszu Społecznego (EFS) oraz zwiększyć budżet przeznaczony na szkolenia zawodowe na obszarach wiejskich. Zalecił przy tym wspieranie przystępowania młodych ludzi do spółdzielni, w których otrzymają oni istotne porady na temat udostępniania produktów na rynku, produkcji oraz innych kwestii związanych z prowadzeniem gospodarstwa rolnego. Wezwał też Komisję i państwa członkowskie, by zapewniły więcej szkoleń i usług doradczych przyszłym i obecnym młodym rolnikom, m.in. w zakresie zakładania działalności gospodarczej w rolnictwie, umiejętności technologicznych, finansowych i związanych z przedsiębiorczością, takich jak marketing, tworzenie sieci kontaktów, komunikacja, innowacja, wielofunkcyjność, dywersyfikacja i specjalistyczna wiedza finansowa, jak również by zwiększyły zachęty w zakresie ich mobilności międzynarodowej.

Parlament Europejski uznał też, że powinno się tworzyć otoczenie sprzyjające dopuszczaniu osób młodych do zawodów rolniczych za pośrednictwem struktur zbiorowych i solidarnościowych, takich jak grupy rolne wspólnego gospodarowania (stowarzyszenia rolników), spółdzielnie wspólnego wykorzystywania sprzętu rolniczego, spółdzielnie zajmujące się przetwórstwem i wprowadzeniem produktów rolnych do obrotu, grupy na rzecz wspólnego wykorzystywania siły roboczej, usługi w ramach zastępstwa, grupy

\footnotetext{
18 Ibidem, pkt 45-46.

${ }^{19}$ Ibidem, pkt 49, 53-54.
} 
wzajemnej pomocy, zrzeszenia popularyzujące rolnictwo i innowacyjność, stowarzyszenia rolników konsumentów, sieci między podmiotami rolnymi i podmiotami spoza rolnictwa (LEADER) itp. ${ }^{20}$

W ocenie posłów do PE należy zapewnić młodym rolnikom na obszarach wiejskich możliwość rozwoju gospodarstwa i utrzymania rodziny, gwarantując im m.in. dostęp do oferowanych usług i infrastruktury (np. szybkich łączy szerokopasmowych, szkół i przedszkoli, dróg), jak w przypadku młodych mieszkańców miast. Uznano, że wymiana pokoleniowa opiera się nie tylko na atrakcyjności zawodu rolnika, ale także na zdolności do generowania z uzyskiwanych dochodów wynagrodzenia dla tych, którzy pragną w ten sposób się utrzymywać. W tym celu WPR musi zapewnić im możliwość regulacji rynku, zwłaszcza gdy rynki nie funkcjonują dobrze i są przyczyną sytuacji kryzysowych. Obecna deregulacja rynków wpływa bowiem negatywnie na rozwój rolnictwa i z zasady uderza mocniej w młodych rolników, którzy założyli gospodarstwa i są poważnie zadłużeni ze względu na poniesione na początku działalności nakłady inwestycyjne ${ }^{21}$.

Piąta grupa zaleceń pt. „Usługi publiczne” obejmuje zagadnienia innowacji w rolnictwie oraz stosowania efektywnych praktyk proekologicznych. Posłowie do PE uznali, że rozwój nowoczesnych ekologicznych praktyk rolnych i nowe modele biznesowe uczynią rolnictwo bardziej atrakcyjnym dla młodych rolników. Uznali, że młodzi rolnicy muszą być wyszkoleni i wykwalifikowani w zakresie najnowszych technologii, aby sprostać obecnym i przyszłym wyzwaniom środowiskowym. Podkreślili potrzebę wspierania innowacyjnych i niekonwencjonalnych podejść, takich jak agroekologia, nowe modele biznesowe oparte na użytkownikach końcowych, cyfrowe technologie rolne i inteligentne rozwiązania, oraz wezwali Komisję, aby zapewniła uwzględnienie tej kwestii w przyszłej WPR.

Parlament Europejski wezwał też Komisję do zintensyfikowania badań nad wykorzystaniem technologii i praktyk rolniczych umożliwiających prowadzenie zrównoważonego rolnictwa o niewielkim wpływie na środowisko. Jego zdaniem w celu zapewnienia konkurencyjności rolnictwu w UE niezbędne jest tworzenie i utrzymywanie nowych miejsc pracy, promowanie innowacyjności oraz cyfryzacja w dziedzinie kształcenia zawodowego dla rolników ${ }^{22}$.

W dalszej części rezolucji Parlament Europejski podkreślił, że rolnicy potrzebują dostępu do infrastruktury, przystępnych cenowo i wysokiej jakości obiektów i usług publicznych, w tym opieki zdrowotnej, edukacji, szybkich łączy szerokopasmowych, pomocy, szkoleń, usług kulturalnych, urzędów

${ }^{20}$ Ibidem, pkt 58, 60, 62-63, 65, 68.

${ }^{21}$ Ibidem, pkt 68, 71.

${ }^{22}$ Ibidem, pkt 72-73. 
pocztowych, transportu publicznego oraz dróg. Zwrócono się też do Komisji i państw członkowskich o zaangażowanie się w tworzenie bezpośrednich kanałów wprowadzania produktu do obrotu, umożliwiających młodym rolnikom ich sprzedaż na rynkach lokalnych w bardziej zrównoważony sposób i z większym zyskiem. Posłowie wezwali też Komisję do opracowania „agendy wiejskiej”, która miałaby obejmować skoordynowane działania w ramach różnych unijnych, krajowych, regionalnych i lokalnych polityk rozwoju obszarów wiejskich, wskazując, że WPR wymaga inteligentnych podejść, ponieważ nowe rozwiązania stanowią o atrakcyjności życia na obszarach wiejskich dla młodych ludzi ${ }^{23}$.

Zalecenia rezolucji PE zawarte w grupie pt. „Środki mające na celu walkę z wyludnianiem się obszarów wiejskich" wyrażają dostrzeżoną przez Parlament Europejski konieczność zaoferowania młodym rolnikom długoterminowej perspektywy rozwoju, co ma zapobiec wyludnianiu się obszarów wiejskich. Zwrócono się więc do Komisji i państw członkowskich o rozważenie nowych inicjatyw mających zagwarantować dostateczną infrastrukturę na obszarach wiejskich w celu wspierania nowych przedsiębiorców i ich rodzin. Wskazano na potrzebę harmonizacji działań w ramach programów rozwoju obszarów wiejskich i pierwszego filaru WPR, działań w ramach unijnej polityki spójności oraz działań na szczeblu krajowym, regionalnym i lokalnym w celu zwiększenia ich skuteczności. Komisja została też zobowiązana, aby w ramach przyszłej reformy WPR ukierunkowała płatności bezpośrednie na małe gospodarstwa i rolnictwo agroekologiczne, ponieważ przyniesie to niezwykle duże korzyści młodszym rolnikom i rolnikom rozpoczynającym działalność. W rezolucji stwierdzono, że intensywne wsparcie młodych rolników i rozwój nowych aktywności gospodarczych w sektorze rolnym w UE to środki, które zdecydują o przyszłości obszarów wiejskich, i dlatego należy je utrzymać w ramach nowej WPR po $2020 \mathrm{r}^{24}$

W grupie zaleceń pt. „Środowisko i zrównoważony rozwój” Parlament Europejski wezwał Komisję do zapewnienia większej spójności środków ochrony środowiska oraz ich harmonizacji, przypominając, że środki przewidziane dla młodych rolników muszą być czytelne i łatwe do wdrożenia. W rezolucji PE wyrażono też pogląd, że aby utrzymać zaludnienie obszarów wiejskich oraz zapewnić osobom tam mieszkającym standard życia podobny do standardu życia w miastach, należy usunąć bariery regulacyjne i administracyjne, aby umożliwić rolnikom prowadzenie uzupełniającej działalności rolniczej i działalności pozarolniczej, zapewniając tym samym odpowiednie

\footnotetext{
${ }^{23}$ Ibidem, pkt 74-75, 77-78.

${ }^{24}$ Ibidem, pkt 79-80, 82, 84-86.
} 
dochody rolnikom i ich rodzinom oraz zmniejszając ryzyko wyludniania się wsi. Z tych względów wezwano do podjęcia dialogu ze społeczeństwem na temat przyszłości sektora rolno-spożywczego w celu przedstawienia rzeczywistego obrazu działalności rolnej oraz poszerzania wiedzy dotyczącej zawodu rolnika i wytwarzania produktów spożywczych ${ }^{25}$.

Rezolucję PE zamykają zalecenia objęte tytułem „Inne”. Komisja i państwa członkowskie zostały wezwane, by podjąć środki w celu zabezpieczenia dochodów rolników na wypadek zagrożeń klimatycznych, sanitarnych i ekonomicznych oraz zwiększenia w ten sposób odporności gospodarstw rolnych, w szczególności przez wdrożenie nowych narzędzi zarządzania ryzykiem i wzmocnienie już istniejących. Podkreślono, że małe i rodzinne gospodarstwa, które funkcjonują $\mathrm{w}$ utrudnionych warunkach i poszukują dla siebie dodatkowego dochodu, powinny być silniej wspierane, np. przez finansowanie usług doradczych lub innowacyjnych modeli biznesowych. Polityka strukturalna powinna również obejmować wymianę międzypokoleniową z korzyścią dla młodych i starszych rolników, uwzględniając znaczenie sporządzania przez rolników planów dziedziczenia gospodarstw i potrzebę istnienia płatności przejściowej ułatwiającej takie dziedziczenie ${ }^{26}$.

\section{Instrumenty wsparcia młodych rolników w polskim prawie rolnym}

Rola wsparcia młodych rolników jest w polskim prawodawstwie oraz piśmiennictwie prawniczym i ekonomicznym dość wyraźnie dostrzegana. Wpływ na wzrost krajowego zainteresowania tą problematyką miała integracja Polski z Unią Europejską, a zwłaszcza wdrożenie stosowanych w niej instrumentów WPR. Można ocenić, że w III RP przed 2004 r. polski prawodawca wykazywał zainteresowanie następcami w gospodarstwach rolnych głównie z uwagi na regulację sytuacji prawnej rolników kończących swą aktywność zawodową ${ }^{27}$. Przykładem są instytucje ściśle powiązane z problematyką rolniczo-emerytalną, takie jak umowa z następcą ${ }^{28}$ czy krajowe

${ }^{25}$ Ibidem, pkt 87-89.

${ }^{26}$ Ibidem, pkt 90, 92-93.

${ }^{27}$ R. Budzinowski, Problemy ludzi starszych na wsi w aspekcie prawnym, „Ruch Prawniczy, Ekonomiczny i Socjologiczny" 1999, z. 1, s. 199-212.

${ }_{28}$ Art. 84-91 ustawy z 20 grudnia 1990 r. o ubezpieczeniu społecznym rolników (tekst jedn. Dz. U. z 2020 r., poz. 174 ze zm.). Por. R. Budzinowski, Umowa z nastęca, w: J. Panowicz-Lipska (red.), System prawa prywatnego, t. 8: Prawo zobowiąań - część szczegółowa, Warszawa 2011; M. Niedośpiał, Umowa z następca, Bielsko-Biała 1996. 
renty strukturalne ${ }^{29}$. W doktrynie ocenia się, że umowy z następcą najlepiej odpowiadają potrzebom społecznym w zakresie dostępnych mechanizmów wymiany pokoleniowej w rolnictwie, ponieważ zmianę pokoleniową traktuje się z założenia jako długotrwały proces, $\mathrm{w}$ którym samo przeniesienie własności stanowi tylko jeden $\mathrm{z}$ jego etapów ${ }^{30}$. Nie jest to jednak umowa często w praktyce stosowana. Natomiast krajowe renty strukturalne nie odegrały przypisanej im przez ustawodawcę roli, ponieważ państwo nie zaangażowało w to odpowiednich środków budżetowych. Natomiast w ramach stymulowania przemian pokoleniowych na obszarach wiejskich na przełomie XX i XXI wieku duże znaczenie miały kredyty na utworzenie lub urządzenie gospodarstwa rolnego, z dopłatami do oprocentowania ze środków Agencji Restrukturyzacji i Modernizacji Rolnictwa (ARiMR), realizowane przez osoby, które nie przekroczyły 40. roku życia ${ }^{31}$. Ta forma wsparcia cieszyła się największym zainteresowaniem i stanowiła 35,7\% udzielonych kredytów inwestycyjnych i 43,2\% ich łącznej kwoty ${ }^{32}$.

Istotne zmiany w polityce wsparcia kierowanego do młodych rolników zaszły po przystąpieniu Polski do Unii Europejskiej33, choć pomoc ta była adresowana nie do wszystkich młodych, lecz tych rozpoczynających działalność rolniczą. Zasadniczo subsydia i preferencje na rzecz młodych rolników służą oddziaływaniu w trzech obszarach: zmiany pokoleniowej rolników i zapewnienia ciągłości gospodarowania $\mathrm{w}$ rolnictwie, poprawy struktury agrarnej oraz poprawy konkurencyjności, rozumianej jako efektywność ekonomiczna rolnictwa ${ }^{34}$. Na tym tle oraz w kontekście zaleceń ujętych w rezolucji PE warto przeanalizować obecnie stosowane prawno-ekonomiczne instrumenty wsparcia udzielanego młodym rolnikom w Polsce.

W ramach polityki rozwoju obszarów wiejskich najbardziej powszechną formą dotowania i mobilizowania aktywności początkujących i zarazem młodych rolników jest działanie Programu Rozwoju Obszarów Wiejskich

${ }^{29}$ Ustawa z 26 kwietnia 2001 r. o rentach strukturalnych w rolnictwie (tekst jedn. Dz. U. z 2018 r., poz. 872).

${ }^{30} \mathrm{P}$. Księżak, Umowy stużące wymianie pokoleń w rolnictwie. Umowa z następca, w: M. Korzycka (red.), Instytucje prawa rolnego, Warszawa 2019, s. 350.

31 Zob. § 11 ust. 3 pkt 3 rozporządzenia Rady Ministrów z 30 stycznia 1996 r. w sprawie szczegółowych kierunków działań Agencji Restrukturyzacji i Modernizacji Rolnictwa oraz sposobów ich realizacji (Dz. U. Nr 16, poz. 82 ze zm.).

32 W latach 1995-2003 młodym rolnikom udzielono 103573 kredyty preferencyjne na łączną kwotę 7256650000 zł. Zob. W. Pomajda (red.), ARiMR - rok po akcesji, Warszawa 2005, s. 15.

${ }^{33}$ K. Stefańska, Sytuacja prawna młodych rolników w procesie zmiany generacji w rolnictwie, „Studia Iuridica Agraria” 2011, t. IX, s. 172-184.

${ }^{34}$ M. Adamowicz, A. Szepeluk, Wsparcie młodych rolników jako element polityki rolnej Unii Europejskiej, ,Zagadnienia Ekonomiki Rolnej” 2016, nr 3(348), s. 107. 
na lata 2014-2020 (PROW) „Rozwój gospodarstw rolnych i działalności gospodarczej” ${ }^{35}$, w ramach którego wyodrębniono poddziałanie (6.1) „Pomoc w rozpoczęciu działalności gospodarczej na rzecz młodych rolników"36. Zakłada ono finansowanie ze środków PROW operacji „Premie dla młodych rolników", które wpisują się w realizację celu szczegółowego PROW nr 2B: „ułatwianie wejścia rolników posiadających odpowiednie umiejętności do sektora rolnictwa, a w szczególności wymiany pokoleń”. Wsparcie kierowane jest do osób w wieku do 40 lat, posiadających odpowiednie kwalifikacje zawodowe, które pierwszy raz podejmują się prowadzenia gospodarstwa rolnego. Instrument ten służy także realizacji priorytetu 2, mającego na celu zwiększenie konkurencyjności gospodarstw rolnych, gdyż pomoc kierowana jest wyłącznie do gospodarstw o odpowiedniej wielkości ekonomicznej i fizycznej, a prowadzący je rolnicy zobowiązani są do przedstawienia ukierunkowanego na rozwój biznesplanu.

Jeśli zaś chodzi o wpisywanie się instrumentu w przyjęte cele przekrojowe PROW, to założono, iż skierowanie pomocy do beneficjentów w młodym wieku przyczyni się do wprowadzania innowacyjnych metod w gospodarstwach rolnych, dotyczących zarówno produktu, jak i organizacji oraz technologii produkcji, a także będzie sprzyjać wdrażaniu przez młodych rolników rozwiązań korzystnych dla ochrony środowiska i łagodzenia zmian klimatu. Udzielana $w$ ramach omawianego poddziałania pomoc na rozwój działalności rolniczej oraz na przygotowanie do sprzedaży wytwarzanych w gospodarstwie produktów rolnych ma formę premii w wysokości 150 tys. zł, wypłacanej w dwóch ratach: $80 \%$ po spełnieniu zastrzeżonych w decyzji administracyjnej warunków przyznania wsparcia, na co rolnik ma 9 miesięcy od dnia doręczenia decyzji o przyznaniu pomocy, a $20 \%$ po realizacji biznesplanu, czyli po upływie nie więcej niż 3 lat od dnia wypłaty pierwszej raty, po wykazaniu osiągnięcia celu w postaci wzrostu wielkości ekonomicznej gospodarstwa o co najmniej $10 \%{ }^{37}$.

${ }^{35}$ Zob. PROW, pkt 8.2.6.2.

${ }^{36}$ Art. 3 ust. 1 pkt 6 lit. a ustawy z 20 lutego 2015 r. o wspieraniu rozwoju obszarów wiejskich z udziałem środków Europejskiego Funduszu Rolnego na rzecz Rozwoju Obszarów Wiejskich w ramach Programu Rozwoju Obszarów Wiejskich na lata 2014-2020 (tekst jedn. Dz. U. z 2020 r., poz. 217 ze zm.).

${ }^{37}$ Rozporządzenie Ministra Rolnictwa i Rozwoju Wsi z 13 lipca 2015 r. w sprawie szczegółowych warunków i trybu przyznawania, wypłaty oraz zwrotu pomocy finansowej na operacje typu „Premie dla młodych rolników” w ramach poddziałania „Pomoc w rozpoczęciu działalności gospodarczej na rzecz młodych rolników” objętego Programem Rozwoju Obszarów Wiejskich na lata 2014-2020 (tekst jedn. Dz. U. z 2018 r., poz. 759 ze zm.); P. Litwiniuk, Program Rozwoju Obszarów Wiejskich jako dokument programowy i źródto prawa rolnego, Warszawa 2018, s. 83-84. 
Instrument ten w swej obecnej postaci (początkowe wersje doprowadziły jednak do formalnego rozdrobnienia struktury agrarnej w Polsce) sprzyja tworzeniu i obejmowaniu na zasadzie sukcesji gospodarstw rolnych, spełniających rozsądne w polskich warunkach normy obszarowe, przez osoby stosunkowo młode, wykwalifikowane i posiadające biznesplan działalności rolniczej. Można tylko żałować, że wsparcia dla młodych rolników w obecnym okresie programowania nie połączono, choćby opcjonalnie, z przyznawaniem pomocy $\mathrm{w}$ ramach znanego $\mathrm{z}$ poprzednich programów działania „Renty strukturalne”, które pochłaniało istotną część alokacji finansowej przewidzianej na realizację PROW.

Innym instrumentem wspierania młodych rolników w Polsce, opracowanym w ramach polityki pierwszego filaru WPR, są płatności dla młodych rolników, o których mowa w art. 50 rozporządzenia Parlamentu Europejskiego i Rady (UE) nr 1307/2013 z 17 grudnia 2013 r. ustanawiającego przepisy dotyczące płatności bezpośrednich dla rolników na podstawie systemów wsparcia $\mathrm{w}$ ramach wspólnej polityki rolnej oraz uchylającego rozporządzenie Rady (WE) nr 637/2008 i rozporządzenie Rady (WE) nr 73/200938 oraz w art. 13 ustawy z 5 lutego 2015 r. o płatnościach w ramach systemów wsparcia bezpośredniego ${ }^{39}$. Płatność dla młodych rolników wypłacana jest corocznie producentom rolnym, którzy są uprawnieni do płatności w ramach systemu jednolitej płatności obszarowej, o którym mowa w art. 72 ust. 1 rozporządzenia (UE) nr 1306/2013 $3^{40}$, jeżeli pierwszy raz podejmują się prowadzenia działalności w gospodarstwie rolnym jako kierujący nim lub gdy rozpoczęli działalność w gospodarstwie rolnym w ciągu 5 lat przed pierwszym złożeniem wniosku w ramach systemu jednolitej płatności obszarowej, pod warunkiem że wiek wnioskodawcy w roku składania wniosku nie przekracza 40 lat. Płatność ta przysługuje do powierzchni gruntów objętych obszarem zatwierdzonym dla tego rolnika do jednolitej płatności obszarowej nie większej niż 50 ha. Stawka płatności dla młodego rolnika za 2020 r. wynosi w Polsce 256,62 zł na hektar powierzchni obszaru zatwierdzonego do tej płatności ${ }^{41}$.

$\mathrm{Z}$ posiadaniem statusu młodego rolnika $\mathrm{w}$ rozumieniu PROW wiążą się także preferencje $\mathrm{w}$ ramach nowego reżimu obrotu nieruchomościami

38 Dz. Urz. UE L 2013.347.608 ze zm.

39 Tekst jedn. Dz. U. z 2020 r., poz. 1341.

40 Rozporządzenie Parlamentu Europejskiego i Rady (UE) nr 1306/2013 z 17 grudnia 2013 r. w sprawie finansowania wspólnej polityki rolnej, zarządzania nią i monitorowania jej oraz uchylające rozporządzenia Rady (EWG) nr 352/78, (WE) nr 165/94, (WE) nr 2799/98, (WE) nr 814/2000, (WE) nr 1290/2005 i (WE) nr 485/2008 (Dz. Urz. UE L 2013.347.549 ze zm.).

41 Rozporządzenie Ministra Rolnictwa i Rozwoju Wsi z 14 października 2020 r. w sprawie stawki płatności dla młodego rolnika za 2020 r. (Dz. U. poz. 1811). 
rolnymi, ustanowionego przepisami ustawy z 11 kwietnia 2003 r. o kształtowaniu ustroju rolnego ${ }^{42}$. Zgodnie z art. 2a ust. 4 pkt 3 u.k.u.r. osoba fizyczna zamierzająca powiększyć gospodarstwo rolne może pod określonymi w przywołanym przepisie szczegółowymi warunkami wystąpić do dyrektora generalnego Krajowego Ośrodka Wsparcia Rolnictwa (KOWR) o wyrażenie zgody na nabycie nieruchomości rolnej, jeżeli przyznano jej pomoc objętą zakresem operacji „Premie dla młodych rolników” w ramach PROW na lata 2014-2020, a nabycie nieruchomości rolnej będzie zgodne z warunkami przyznanej pomocy. Nabycie w tym trybie może także nastąpić do majątku wspólnego ${ }^{43}$.

Tego rodzaju preferencjami ustawowymi objęte jest również nabycie nieruchomości rolnej w celu utworzenia gospodarstwa rodzinnego, o czym przesądza art. 2a ust. 4 pkt 2 u.k.u.r. W literaturze wskazuje się, że wnioskodawca mimo posiadania kwalifikacji rolniczych nie jest jeszcze rolnikiem indywidualnym w jego ustawowej postaci, gdyż nie spełnia wszystkich przesłanek określonych $\mathrm{w}$ art. 6 u.k.u.r. Status taki uzyska dopiero po upływie 5-letniego okresu ${ }^{44}$. $\mathrm{Z}$ tych względów gospodarstwo rolne tworzone przez nowego rolnika, o którym mowa w omawianym przepisie, określane jest w literaturze mianem ,gospodarstwa rodzinnego w trakcie tworzenia" ${ }^{45}$. Ponadto art. 2 b ust. 4 pkt 1 lit. e u.k.u.r. wyłącza obowiązek nabywcy nieruchomości rolnej prowadzenia gospodarstwa rolnego, w skład którego weszła nabyta nieruchomość rolna, przez okres co najmniej 5 lat od dnia nabycia przez niego tej nieruchomości, w sytuacji gdy dokona jej zbycia na rzecz osoby, której przyznano pomoc w ramach operacji PROW „Premie dla młodych rolników".

Młodzi rolnicy, w rozumieniu przepisów o rozwoju obszarów wiejskich ze środków Europejskiego Funduszu Rolnego na rzecz Rozwoju Obszarów Wiejskich (EFRROW), zostali również uwzględnieni w objętej przepisami ustawy z 19 października 1991 r. o gospodarowaniu nieruchomościami rolnymi Skarbu Państwa ${ }^{46}$ regulacji zbywania w drodze przetargu nieruchomości rolnych z Zasobu Własności Rolnej Skarbu Państwa (ZWRSP). Zgodnie $\mathrm{z}$ art. 29 ust. 3 bb tej ustawy KOWR może organizować przetargi ograniczone, w których oprócz rolników indywidualnych, w rozumieniu przepisów

${ }^{42}$ Tekst jedn. Dz. U. z 2020 r., poz. 1655 [dalej: u.k.u.r.].

${ }^{43}$ W. Gonet, Komentarz do art. $2 a$, w: P.A. Blajer, W. Gonet, Ustawa o ksztaltowaniu ustroju rolnego. Komentarz, Warszawa 2020, s. 135.

${ }^{44}$ D. Łobos-Kotowska, M. Stańko, Ustawa o kształtowaniu ustroju rolnego. Komentarz, Warszawa 2020, s. 119.

45 J. Bieluk, Ustawa o ksztaltowaniu ustroju rolnego, Warszawa 2019, s. 162.

46 Tekst jedn. Dz. U. z 2020 r., poz. 396 ze zm. 
u.k.u.r., może uczestniczyć również osoba, która nie spełnia jedynie wymogu dotyczącego 5-letniego okresu osobistego prowadzenia gospodarstwa rolnego, w przypadku gdy osoba ta w dniu ogłoszenia wykazu nieruchomości przeznaczonych do sprzedaży na stronie podmiotowej Biuletynu Informacji Publicznej KOWR ma nie więcej niż 40 lat lub gdy spełnia warunki określone w decyzji o przyznaniu pomocy w ramach operacji „Premie dla młodych rolników”. Ostatni z wymienionych beneficjentów omawianej regulacji objęci są także zwolnieniem z obowiązku posiadania wymaganych kwalifikacji rolniczych przez okres, w trakcie którego powinny być one uzupełnione zgodnie z decyzją dyrektora oddziału regionalnego ARiMR w przedmiocie przyznania premii dla młodych rolników, tj. maksymalnie przez 3 lata od dnia doręczenia takiej decyzji wnioskodawcy ${ }^{47}$.

Ustawodawca w art. 29a ust. 4 pkt 1 lit. c omawianego aktu prawnego upoważnił KOWR do zwolnienia nabywcy nieruchomości rolnej z ZWRSP z sankcjonowanego karą umowną obowiązku nieprzenoszenia własności nabytej nieruchomości przez okres 15 lat oraz prowadzenia na niej w tym okresie działalności rolniczej, a w przypadku osób fizycznych - do osobistego prowadzenia tej działalności w sytuacji, gdy przeniesienie własności takiej nieruchomości ma nastąpić na rzecz beneficjenta pomocy w ramach operacji „Premie dla młodych rolników”.

Jeśli zaś chodzi o wykorzystywane przez młodych rolników instrumenty wsparcia ustanowione $\mathrm{w}$ ramach pomocy krajowej, to można wyróżnić przewidziane w art. 12 ust. 1 pkt 4 ustawy z 15 listopada 1984 r. o podatku rolnym ${ }^{48}$ zwolnienie z podatku rolnego, którym objęto grunty przeznaczone na utworzenie nowego gospodarstwa rolnego lub powiększenie już istniejącego do powierzchni nieprzekraczającej 100 ha, będące przedmiotem prawa własności lub prawa użytkowania wieczystego, nabyte w drodze umowy sprzedaży, będące przedmiotem umowy o oddanie gruntów w użytkowanie wieczyste albo wchodzące w skład ZWRSP, objęte przez rolnika w trwałe zagospodarowanie.

Okres zwolnienia z obowiązku podatkowego wynosi 5 lat, licząc od pierwszego dnia miesiąca następującego po miesiącu, w którym zawarto umowę sprzedaży gruntów lub prawa wieczystego użytkowania, ustanowiono prawo wieczystego użytkowania gruntów lub objęto grunty w trwałe zagospodarowanie w drodze umowy. Po upływie okresu omawianego zwolnienia stosuje się ulgę $\mathrm{W}$ podatku rolnym, polegającą na obniżeniu podatku w pierwszym roku o $75 \%$ i w drugim roku o $50 \%$. Przedstawione zwolnienie

${ }^{47}$ P. Iwaszkiewicz, Teza 7, w: P. Czechowski (red.), Ustawa o gospodarowaniu nieruchomościami rolnymi Skarbu Państwa. Komentarz, Warszawa 2018, s. 207-208.

${ }^{48}$ Tekst jedn. Dz. U. z 2020 r., poz. 333. 
i ulga w podatku rolnym stanowią pomoc de minimis w rolnictwie, o której mowa w rozporządzeniu Komisji (UE) nr 1408/2013 z 18 grudnia 2013 r. w sprawie stosowania art. 107 i 108 Traktatu o funkcjonowaniu Unii Europejskiej do pomocy de minimis $\mathrm{w}$ sektorze rolnym ${ }^{49}$.

Należy dodać, że ARiMR udziela także pomocy finansowej z przeznaczeniem na tworzenie lub powiększenie gospodarstw rolnych przez młodych rolników, o których mowa w art. 2 pkt 34 rozporządzenia Komisji (UE) nr 702/2014 z 25 czerwca 2014 r. uznającego niektóre kategorie pomocy w sektorach rolnym i leśnym oraz na obszarach wiejskich za zgodne z rynkiem wewnętrznym w zastosowaniu art. 107 i 108 Traktatu o funkcjonowaniu Unii Europejskiej ${ }^{50}$, w ramach której uruchomiono linię kredytów preferencyjnych z częściową spłatą kapitału na zakup użytków rolnych przez młodych rolników (tzw. linia MRcsk). W ramach tego instrumentu pomocowego beneficjenci mogą otrzymać częściową spłatę kredytu, maksymalnie do równowartości w złotych 20 tys. euro. Budżet naboru otwartego w 2020 r. wynosi $30 \mathrm{mln} \mathrm{z}^{51}$.

Trzeba jednak stwierdzić, że ani polskie prawo spadkowe, ani przepisy regulujące warunki nabycia praw emerytalnych przez przekazujących gospodarstwa rolne nie zawierają jakichkolwiek preferencji dla młodych rolników, zaś te ostatnie regulacje - ze względu na podniesienie wieku emerytalnego dla rolników - wręcz pogorszyły warunki zmiany pokoleniowej na obszarach wiejskich.

\section{Podsumowanie}

Z przedstawionych rozważań płynie wniosek, że stosowane w Polsce instrumenty wsparcia młodych rolników wpisują się jedynie w niektóre obszary akcentowane w rezolucji PE. Odnoszą się bowiem zasadniczo do osób rozpoczynających działalność rolniczą, wyłączając z zakresu interwencji szerokie grono młodych rolników, którzy wcześnie rozpoczęli aktywność zawodową i nie są już uważani za rolników „,początkujących”. Ponadto ograniczają się głównie do zachęt finansowych w procesie organizowania lub obejmowania gospodarstw rolnych, w tym do niewielkich ułatwień w nabywaniu nieruchomości rolnych. Pomijają jednak tak istotne aspekty,

${ }^{49}$ Dz. Urz. UE L 2013.352.9.

${ }^{50}$ Dz. Urz. UE L 2014.193.1.

${ }^{51}$ Zob. § 2 ust. 1 pkt 2 rozporządzenia Rady Ministrów z 27 stycznia 2015 r. w sprawie szczegółowego zakresu i sposobów realizacji niektórych zadań Agencji Restrukturyzacji i Modernizacji Rolnictwa (Dz. U. poz. 187 ze zm.). 
jak wspieranie innowacyjności gospodarki rolnej, ułatwianie dostępu do technologii i profesjonalnego doradztwa z zakresu finansów czy zarządzania gospodarstwem.

Rozważania te uprawniają także do sformułowania kilku wniosków de lege ferenda. Przede wszystkim wsparciem należy objąć wszystkich młodych rolników, bez zawężania go wyłącznie do rolników rozpoczynających działalność. Warto też postulować dalsze ułatwienia w dostępie młodych rolników do gruntów, m.in. poprzez wprowadzenie preferencyjnego nabywania gruntów państwowych z ZWRSP, z pierwszeństwem nawet przed rolnikami indywidualnymi, nieposiadającymi statusu młodego rolnika. Co więcej, warto udostępnić młodym rolnikom funkcjonalności prowadzonego przez KOWR portalu eRolnik, czyli systemu teleinformatycznego umożliwiającego nieodpłatne zamieszczanie ogłoszeń o zamiarze sprzedaży nieruchomości rolnych i odpowiedzi na ogłoszenia o nieruchomości rolnej, o którym mowa $\mathrm{w}$ art. 4a u.k.u.r. Istotne znaczenie miałoby też w tym kontekście doprecyzowanie przesłanek oceny przez ARiMR w procesie przyznawania płatności obszarowych rzeczywistego prowadzenia przez wnioskodawcę działalności rolniczej, tak by wyłączyć z prawa do dopłat właścicieli nieruchomości rolnych, którzy w utajony sposób wydzierżawiają je rolnikom. Proponowane zmiany mogłyby się przyczynić do poprawy warunków organizowania i powiększania gospodarstw przez młodych rolników.

Należy zgodzić się z postulatem PE, aby młodzi rolnicy mogli sami decydować o gospodarowaniu własnym gruntami, z zachowaniem swobody i elastyczności. Nakładanie przepisami u.k.u.r. długoletnich zobowiązań w zakresie prowadzenia gospodarstwa rolnego oraz wysokich kar finansowych za przedterminowe zbycie lub zaniechanie rolniczego korzystania z nabytej z ZWRSP nieruchomości rolnej może zniechęcać do podejmowania działalności rolniczej przez młodych, którzy mają przecież prawo do błędu oraz do zmiany sposobu zarobkowania. $Z$ tych względów powinno nastąpić zliberalizowanie obrotu nieruchomościami rolnymi w odniesieniu do tej grupy rolników.

Większą elastycznością sprzyjającą aktywacji działalności rolniczej przez młodych rolników powinna się również cechować regulacja ubezpieczeń społecznych rolników. Obecne wyjątki, pozwalające łączyć ubezpieczenie w KRUS z pozarolniczą działalnością gospodarczą, można uważać za zbyt restryktywne. Przepisy mogłyby dopuszczać także, zgodnie z zaleceniem rezolucji PE, umożliwienie przynajmniej młodym rolnikom prowadzenia uzupełniającej działalności w sektorach opieki społecznej, opieki zdrowotnej, turystyki, mobilności osób starszych czy energetyki. System rolniczych ubezpieczeń społecznych powinien też przeciwdziałać obserwowanemu 
zjawisku późnego obejmowania przez nich gospodarstw rolnych, związanego z ustanowionym obecnie wiekiem emerytalnym rolników.

Młodzi rolnicy napotykają także na trudności administracyjne i proceduralne w dostępie do instrumentów pomocowych. W celu wyeliminowania tego rodzaju problemów należy zapewnić im dostęp do specjalistycznego doradztwa, w tym finansowego i prawnego, a przede wszystkim w przepisach proceduralnych regulujących prowadzenie przez ARiMR postępowań w sprawie przyznania pomocy powrócić do zasad i wartości postępowania administracyjnego wynikających z k.p.a., które zostały w znaczącym zakresie wyłączone w drodze przepisów szczególnych prawa rolnego. Odpowiedniego ujęcia w regulacjach wymaga także kwestia określenia pozycji prawnej kobiet, które w obecnym tradycyjnym modelu gospodarstwa rodzinnego opartego na ustawowej koncepcji podejmującego „wszelkie decyzje” rolnika indywidualnego nie korzystają z pełni należnych im praw.

Konkludując, każda skuteczna strategia na rzecz wymiany pokoleń i wsparcia młodych rolników powinna opierać się na całościowym podejściu, aby ułatwiać im dostęp do ziemi, finansowania, usług doradczych i szkoleń oraz uwzględniać zmianę pokoleń z korzyścią dla młodych i starszych producentów. Natomiast dotychczasowa krajowa polityka, kreująca system wsparcia młodych rolników, mimo niewątpliwych osiągnięć może być w wielu aspektach uważana za nieefektywną, a stosowane rozwiązania prawne uznawane za fragmentaryczne i niekomplementarne wobec siebie.

\section{LEGAL POSITION OF THE YOUNG FARMER IN POLAND IN THE LIGHT OF THE EUROPEAN PARLIAMENT RESOLUTION OF 29 MAY 2018}

\section{Sum mary}

The European Parliament Resolution of 29 May 2018 on the implementation in the EU of CAP tools for young farmers after the 2013 reform draws the attention of EU bodies and European institutions as well as the governments of the Member States to the significant problem of adequate forms and safeguards for the position of young farmers provided for in EU legislation and national regulations. The article presents the reasons for the adoption of the resolution and the recommendations addressed to the Council, the European Commission, the Court of Auditors and the governments and parliaments of the Member States. An analysis of the instruments developed to support young farmers in Poland and facilitate a generational change in rural areas was conducted and it has been found that despite certain unquestionable achievements to date, Polish legal solutions are still largely ineffective, fragmentary and incomplete. 


\section{LA POSIZIONE GIURIDICA \\ DI UN "GIOVANE AGRICOLTORE" IN POLONIA ALLA LUCE DELLA RISOLUZIONE DEL PARLAMENTO EUROPEO DEL 29 MAGGIO 2018}

\section{Riassunto}

La risoluzione del Parlamento europeo del 29 maggio 2018 sull'attuazione degli strumenti della PAC a favore dei giovani agricoltori nell'UE dopo la riforma del 2013 richiama l'attenzione degli organi dell'UE e delle istituzioni europee, nonché dei governi degli Stati membri, su un problema fondamentale che riguarda una adeguata formazione e salvaguardia riguardo alla posizione dei giovani agricoltori all'interno della legislazione dell'UE e delle regolazioni nazionali. L'articolo, oltre a spiegare le ragioni per le quali la risoluzione è stata adottata, presenta anche le raccomandazioni rivolte al Consiglio, alla Commissione europea, alla Corte dei conti, nonché ai governi e ai parlamenti degli Stati membri. Inoltre, l'autore analizza gli strumenti di sostegno a favore dei giovani agricoltori, adottati in Polonia, i quali favoriscono il ricambio generazionale nelle zone rurali. Nella parte conclusiva, è stato appurato che le soluzioni giuridiche adottate siano inefficaci, mentre il loro carattere è frammentario e non complementare 